\title{
REVIEW
}

\section{New insights into Mullerian inhibiting substance and its mechanism of action}

\author{
A H Lane and P K Donahoe \\ Pediatric Surgical Research Laboratories, Massachusetts General Hospital, Boston, Massachusetts 02114, USA \\ (Requests for offprints should be addressed to A H Lane, Pediatric Surgical Research Laboratories, Warren 10, Massachusetts General Hospital, \\ 50 Blossom Street, Boston, Massachusetts 02114, USA)
}

\section{Introduction}

One of the first factors to be secreted by fetal Sertoli cells during mammalian male sexual differentiation is the glycoprotein, Mullerian inhibiting substance (MIS), also known as anti-Mullerian hormone (AMH). MIS initiates the regression of the Mullerian ducts during a single, transient period during sexual development of the male; in the absence of MIS, the Mullerian ducts differentiate into the uterus, fallopian tubes and upper one-third of the vagina in the female (Josso et al. 1977, Lee \& Donahoe 1993). In addition to this principal role for MIS, its continued postnatal expression supports hypotheses that MIS may have other roles such as regulation of gonadal function, testicular descent, lung development and suppression of tumor growth (Lee \& Donahoe 1993, Teixeira \& Donahoe 1996).

\section{Regulation of MIS expression}

The human gene, located on chromosome 19p13.2-13.3 is $4 \mathrm{~kb}$ long, encompassing five exons that yield a $2 \mathrm{~kb}$ mRNA (Cate et al. 1986). MIS mRNA expression is first detected in the mouse testis at 11.5 days post coitus (Munsterberg \& Lovell-Badge 1991) and in the rat testis at 13 days post coitus (Josso et al. 1977), and it continues throughout fetal development. Messenger RNA expression decreases several days after birth and then decreases further peripubertally (Kuroda et al. 1990). MIS expression is first detectable in the female rodent several days after birth and persists throughout life (Munsterberg \& LovellBadge 1991, Hirobe et al. 1992, Taketo et al. 1993). MIS protein expression appears to parallel mRNA expression in the rodent. Serum concentrations of MIS in males increase after birth to a peak in late infancy and then decline until puberty, when they remain stable; in females, MIS is first secreted by the ovaries in low concentrations postnatally and then increases at puberty (Lee et al. 1996).
The proximal 180 base pairs of the mouse MIS promoter appear to be sufficient for activation of MIS expression, and within this region there are several evolutionarily conserved motifs (Dresser et al. 1995, Giuili et al. 1997) (Fig. 1). Using deletion constructs of the -269 to +8 region of the human MIS promoter upstream of a luciferase reporter, we have been able to analyze the roles of the conserved elements. A region between -63 and -49 containing the sequence GTTTGT is protected by the HMG domain of the sex-determining region Y (SRY) protein in DNase footprinting experiments and the SRY HMG domain binds to this sequence in electrophoretic mobility shift assays (Haqq et al. 1993, 1994). As MIS expression in Sertoli cells follows approximately 1 day after the expression of SRY in rodents and shortly after SRY expression during the 7th week of human gestation, SRY is a candidate to regulate MIS expression through binding to this sequence. However, the functional significance of this element remains in question because, although SRY was able to induce expression of a luciferase reporter linked to the MIS promoter, no mutations of the MIS promoter, including mutations or deletions of this $\mathrm{HMG}$ element, were able to diminish this induction. It is possible that SRY requires the presence of an interacting factor to confer specificity for activation of this site.

Another conserved element in the human MIS promoter, the MARE-1 or M-1 site, is located between - 93 and -69 . This sequence conforms to the consensus sequence for the GATA family of transcription factors (Zon et al. 1991). GATA-1 is known to be expressed in adult Sertoli cells; however, in our laboratory, co-transfection of GATA-1 failed to activate an MISpromoter-driven luciferase reporter construct. As novel GATA factors are discovered, they may be similarly tested for functional effects on the MIS promoter.

The M2/MIS-RE1 site (Shen et al. 1994) at position -84 to -103 contains the sequence CCAAGGTCA at the $3^{\prime}$ end, which conforms to the consensus steroidogenic factor 1 (SF1) binding site. SF1, an orphan receptor 


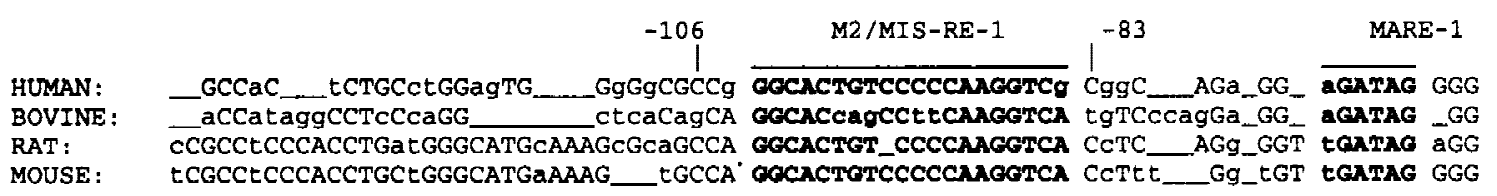

Initiator region

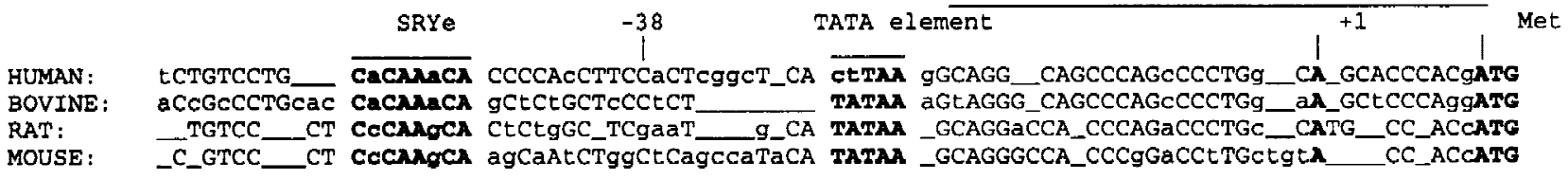

Figure 1 MIS proximal promoter. In numbering the bases of the promoter region, bases are counted from the transciptional start site.

of the steroid nuclear receptor superfamily, is expressed in the male and female mouse urogenital ridge before the expression of MIS and has an important role in normal sexual development (Ikeda et al. 1993). Null mutations of this gene lead to degeneration of the gonads, adrenals, and ventromedial hypothalamus (Luo et al. 1994, Ikeda et al. 1995). Mutations in the MIS-RE1 binding site lead to decreased expression of reporter genes in a postnatal Sertoli cell line and in transgenic mice (Giuili et al. 1997), whereas MIS expression in HeLa cells is induced by SF1 lacking the ligand-binding domain (Shen et al. 1994). In contrast, in our laboratory, when full-length SF1 and an MIS luciferase reporter were co-transfected into an embryonic male urogenital ridge-derived cell line, luciferase expression was decreased (Haqq et al. 1994). Thus, although it appears that SF1 may activate MIS expression, the precise nature of the interactions of SF1 with the MIS promoter remain unclear and may be developmentally dependent.

The human MIS gene does not contain a consensus TATA or initiator element (Cate et al. 1986, Guerrier et al. 1989). Experimental mutations in the human MIS promoter in our laboratory have identified the -6 to +10 region as containing a putative initiator site ( $\mathrm{N}$ Morikawa, $\mathrm{T}$ Clarke, K Watanabe \& P K Donahoe, unpublished observations). This region formed specific DNA-protein complexes with nuclear extracts from a 14.5 day post coitus rat urogenital ridge-derived cell line, and with purified transcription factor II (TFII)-I in electrophoretic mobility shift assays. Polyclonal antibodies were able to block the initiator TFII-I complexes, and excess molar amounts of initiators of other genes, such as the T-cell receptor-driven variable region $\mathrm{B}$ chain gene and terminal deoxynucleotidyl transferase, were able to compete with the complex. Thus human MIS may be initiator-driven via an initiator site that is distinct from the typical initiator consensus, $\mathrm{PyPy}(\mathrm{A}+1) \mathrm{NT} / \mathrm{APyPy}$.

\section{MIS signaling}

MIS is a homodimeric glycoprotein linked by disulfide bonds, with a molecular mass of $140 \mathrm{kDa}$ (Cate et al.
1990). Along with the activins, inhibin, bone morphogenesis proteins, Drosophila's decapentaplegic, Vg-1 and a host of newly discovered growth and differentiation factors, it is a member of the transforming growth factor (TGF)- $\beta$ family (Cate et al. 1990, Massague et al. 1994). The MIS molecule must be proteolytically cleaved between R427 and S428 to generate the bioactive carboxy (C)-terminal fragment (MacLaughlin et al. 1992, Pepinsky et al. 1988), which is a characteristic shared amongst many family members (Massague 1990). Furin and PC5, proprotein convertases expressed in the urogenital ridge, are candidate MIS processing enzymes that, by their temporal and spatial expression, may help confer tissue specificity to the actions of MIS actions (Nachtigal \& Ingraham 1996). MIS is glycosylated at its amino (N) terminus, but the functional significance of this is unknown, as the $\mathrm{N}$ terminus does not appear to exhibit activity in an organ culture bioassay system, whereas holo-MIS and C-terminal MIS are active (Cate et al. 1990, MacLaughlin et al. 1992). Without the $\mathrm{N}$ terminus to confer stability, the half life of C-terminal MIS in serum is markedly reduced ( $\mathrm{R} \mathrm{C}$ Ragin \& P K Donahoe, unpublished observations).

The actions of TGF- $\beta$ family members are mediated by single transmembrane-spanning serine/threonine kinase receptors classified as types I and II. The type I and type II receptors share approximately 40\% homology between their kinase domains. There is evidence that the type II receptors bind to ligand and then can recruit the type I receptors into a tetraheteromeric complex of two type II and two type I receptors (Fig. 2). Some of the type I receptors, such as Alk2 and Alk4 are shared by different type II receptors (Franzen et al. 1993). Of the multiple type I receptors that have been cloned, Alk2 is a candidate MIS type I receptor, as it is expressed around the Mullerian duct as it regresses ( $\mathrm{He}$ et al. 1993).

The MIS type II receptor is expressed in the cells surrounding the fetal Mullerian duct, in fetal gonads during the period of sex determination and Mullerian duct regression, and in pubertal and adult rat gonads. The type II receptor mRNA temporal and tissue-specific patterns of 


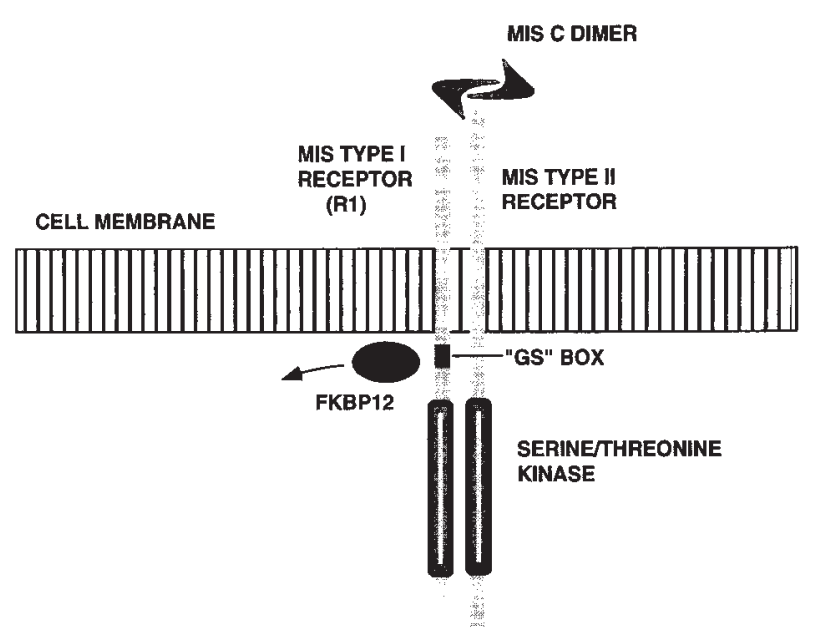

Figure 2 Model for MIS receptor signaling. A homodimer of MIS disulfide-linked at the carboxy-terminus binds to the extracellular cysteine-rich domain of the type II receptor. Downstream signaling occurs when the type I receptor is recruited and phosphorylated by the MIS-type II complex, which releases the negative inhibition exerted by FKBP12. (Reproduced with permission from Teixeira et al. 1996.)

expression have been shown to match that of MIS (Teixeira et al. 1996a,b).

All the type I receptors of the TGF- $\beta$ family bind to FKBP12, a cytosolic protein known to bind the immunosuppressant macrolides, FK506 and rapamycin (Wang et al. 1994). Our current model postulates that binding of the MIS ligand to the receptor complex results in the phosphorylation of the type I receptor by the type II receptor, followed by the release of FKBP12, thus removing the inhibition of signal transduction by FKBP12 (Wang et al. 1996). Other members of the TGF- $\beta$ type I receptor family have been shown to signal downstream through phosphorylation of members of the Smad family. These proteins, among others, are being investigated as substrates for the putative MIS type I receptor.

\section{Physiological effects of MIS}

The Mullerian ducts of male or female rat fetuses will regress fully in response to MIS until 15 days post coitus, but not after that (Donahoe et al. 1977, Josso et al. 1977). Evidence exists that MIS indirectly causes the dissolution of the Mullerian duct epithelium in the rat by its effects on the mesenchyme surrounding the Mullerian duct (Tsuji et al. 1992). This irreversible dissolution in the human fetus occurs by 51 days post ovulation (Taguchi et al. 1984). Failure of the analogous events to occur in the male human fetus leads to the persistent Mullerian duct syndrome (PMDS), in which $46 \mathrm{XY}$ males have normal external genitalia but have a cervix, uterus and fallopian tubes. Although many men with PMDS are infertile and have unilateral or bilateral undescended testes, with
Mullerian structures herniated into the inguinal canal, some are able to father children. Fifty percent of the cases of PMDS can be attributed to mutations in the MIS gene; in the remainder there is a mutation in the type II receptor, such as a deletion of exon 10 (Imbeaud et al. 1996). A patient with Mullerian duct retention has also been found to have a mutation in the splice donor site of intron two of the type II receptor, producing a receptor that failed to localize at the cell surface (Faure et al. 1996). Male MIS type II receptor-deficient mice display a phenotype of retained uterus and oviducts (Mishina et al. 1996), recapitulating that seen with MIS ligand knockout mice (Behringer et al. 1994) and in men with PMDS.

Although MIS does not appear to be essential for testicular differentiation in the male, it may affect subsequent testicular function. Focal Leydig cell hyperplasia and Leydig cell tumors were found in otherwise histologically normal testes of MIS-deficient male mice, while feminization and undescended testes were observed in some MIS overexpressing mice, presumably as a result of reduced Leydig cell androgen production (Behringer et al. 1990, 1994). A postnatal decline in MIS concentrations in the male occurs in parallel with the initiation of spermatogenesis and the intratesticular increase in testosterone (Cate \& Wilson 1993, Al-Attar et al. 1997), and sperm isolated from adult MIS-deficient mice have normal morphological characteristics and functional abilities (Behringer et al. 1994), suggesting that MIS regulates the timing of spermarche, but is not required for spermatogenesis.

Intra-abdominal descent of the testes during fetal development is guided by caudal enlargement of the gubernaculum and recession of the cranial suspensory ligament, events which may be under the direction of MIS (Hutson et al. 1997). Most patients with PMDS do not have testes correctly situated in the scrotum and have hypermobile testes, presumably because of a thin, elongated gubernaculum. This may indicate a role for MIS in the normal swelling of the gubernaculum (Hutson et al. 1994). In contrast to this, the testes of MIS-deficient and MIS-receptor-deficient mice undergo normal transabdominal descent (Behringer et al. 1994), suggesting either species differences or redundancy in MIS function. Thus any role that MIS may have in the descent of the testis remains unclear.

The freemartin effect occurs when a female fetus is exposed to the blood of a male twin in utero. In addition to MIS-directed Mullerian regression in the freemartin female, the ovarian germ cells regress, and the ovaries develop seminiferous tubules containing Sertoli cells. Female transgenic mice overexpressing MIS demonstrate a freemartin effect, with regression of the Mullerian ducts and masculinized ovaries with seminiferous tubules and few germ cells (Behringer 1990). The ability of MIS to redirect ovaries into a more testis-like gonad in females suggests at least an indirect role in male gonadal development. MIS may also have a physiological role in 
the ovary, as MIS in rats is expressed after the first week of life in granulosa cells surrounding only preantral and small antral follicles (Hirobe et al. 1992, Ueno et al. 1989a,b, Baarends et al. 1995). MIS may have an indirect role in the inhibition of oocyte meiosis (Takahashi et al. 1986, Ueno et al. 1989a,b), by blocking aromatase and luteinizing hormone receptor synthesis in granulosa cells (diClemente et al. 1994), but a direct effect remains a possibility, as oocyte meiosis inhibition can be observed in isolated oocytes alone. Notably, MIS is not essential for female gonadal function and attainment of fertility, as MISdeficient female mice are fertile (Behringer et al. 1994).

Respiratory distress syndrome, characterized by decreased surfactant production, is of greater morbidity and mortality in male neonates than in females (Miller \& Futrakul 1968, Torday et al. 1981). The effects of MIS on surfactant accumulation and lung development may contribute to the sex bias of this disorder. MIS decreases the accumulation of disaturated phosphatidylcholine, a component of lung surfactant in fetal rats, and inhibits fetal lung branching morphogenesis in fetal rats by activation of apoptosis (Catlin et al. 1988, 1989, 1997). Proximity of the fetal gonad and lung probably allow this to occur through paracrine secretion of MIS activating the putative type II receptor localized in the embryonic lung (Caitlin et al. 1997).

\section{Clinical applications for MIS}

Serum measurement of MIS is a specific and sensitive marker for the presence of testicular tissue in boys with cryptorchidism. When measured either alone or in tandem with the measurement of human chorionic gonadotrophin stimulated testosterone, MIS concentrations may be used to guide the treatment of these patients. Similarly, serum MIS may be useful in the evaluation of the presence of any functioning testicular tissue in infants and children with ambiguous genitalia (Lee et al. 1997).

Purified MIS has demonstrated antiproliferative effects against vulvar carcinoma and ocular melanoma cell lines (Chin et al. 1991, MacLaughlin et al. 1992, Parry 1992). As ovarian epithelium-derived tumors arise from coelomic epithelium that normally invaginates during fetal development to form the Mullerian duct, this particular type of tumor is potentially responsive to the antiproliferative effects of MIS. Currently, preclinical evidence exists from our laboratory that human ovarian ascites cells from a large percentage of patients with stage III/IV ovarian epithelial cancer bind human recombinant MIS and are growthinhibited by MIS. As a result, clinical trials are being planned to study the efficacy of MIS against epithelial ovarian tumors in humans (P K Donahoe, unpublished observations).

A variety of other types of ovarian tumors have been shown to secrete high levels of MIS. Although these tumors, particularly granulosa cell tumors, are insensitive to any antiproliferative effect of MIS, increases in serum MIS may serve as a marker both of post-surgical residual tumor and of tumor recurrence (Gustafson et al. 1992, Rey et al. 1996). Serial measurements of MIS to allow early detection of recurrence may prove to be especially useful for patients with granulosa cell tumors, which have a poor prognosis in advanced stages (Powell \& Otis 1997).

\section{Summary}

The primary function of MIS in mammals is to initiate regression of Mullerian structures in males as part of normal sexual development. As we learn more about its other roles, particularly its influence on the growth and differentiation of cell types within the gonad, a more thorough understanding of the receptors that MIS stimulates and the downstream signaling cascade with which it interacts will help in the development of diagnostic and therapeutic uses of MIS.

\section{References}

Al-Attar L, Noel K, Dutertre M, Belville C, Forest MG, Burgoyne PS, Josso N \& Rey R 1997 Hormonal and cellular regulation of Sertoli cell anti-Mullerian hormone production in the postnatal mouse. Journal of Clinical Investigation 100 1335-1343.

Baarends WM, Uilenbroek JT, Kramer P, Hoogerbrugge JW, van Leeuwen EC, Themmen AP \& Grootegoed JA 1995 Anti-Mullerian hormone and anti-Mullerian hormone type II receptor messenger ribonucleic acid expression in rat ovaries during postnatal development, the estrous cycle, and gonadotropin-induced follicle growth. Endocrinology 136 4951-4962.

Behringer RR, Cate RL, Froelick GJ, Palmiter RD \& Brinster RL 1990 Abnormal sexual development in transgenic mice chronically expressing mullerian inhibiting substance. Nature 345 167-170.

Behringer RR, Finegold MJ \& Cate RL 1994 Mullerian-inhibiting substance function during mammalian sexual development. Cell $\mathbf{7 9}$ 415-425.

Cate RL \& Wilson CA 1993 Mullerian inhibiting substance. In Genes in Mammalian Reproduction, pp 185-205. Ed RBL Gwatkin. New York: Wiley-Liss.

Cate RL, Mattaliano RJ, Hession C, Tizard R, Farber NM, Cheung A, Ninfa EG, Frey AZ, Gash DJ, Chow EP, Fisher RA, Bertonis JM, Torres G, Wallner BP, Ramachandran KL, Ragin RC, Manganaro TF, MacLaughlin DT \& Donahoe PK 1986 Isolation of the bovine and human genes for Mullerian inhibiting substance and expression of the human genes in animal cells. Cell 45 685-698.

Cate RL, Donahoe PK \& MacLaughlin DT 1990 Mullerian inhibiting substance. In Peptide Growth Factors and Their Receptors II, pp 179-210. Eds MB Sporn \& AB Roberts. Berlin: Springer-Verlag.

Catlin EA, Manganaro TF \& Donahoe PK 1988 Mullerian inhibiting substance depresses accumulation in vitro of disaturated phosphatidylcholine in fetal rat lung. American Journal of Obstetrics and Gynecology 159 1299-1303.

Catlin EA, Powell SM, Manganaro TF, Hudson PL, Ragin RC, Epstein J \& Donahoe PK 1989 Sex-specific fetal lung development and Mullerian inhibiting substance. American Review of Respiratory Disease 141 466-470.

Catlin EA, Tonnu VC, Ebb RG, Pasheco BA, Manganaro TF, Ezzell RM, Donahoe PK \& Teixeira J 1997 Mullerian inhibiting substance inhibits branching morphogenesis and induces apoptosis in fetal rat lung. Endocrinology 138 790-796. 
Chin T, Parry RL \& Donahoe PK 1991 Human Mullerian inhibiting substance inhibits tumor growth in vitro and in vivo. Cancer Research 51 2101-2106.

diClemente N, Goxe B, Remy JJ, Cate RL, Josso N, Vigier B \& Salesse R 1994 Effect of AMH upon aromatase activity and LH receptors of granulosa cells of rat and porcine immature ovaries. Endocrine 2 553-558.

Donahoe PK, Ito Y \& Hendren WH 1977 A graded organ culture assay for the detection of Mullerian inhibiting substance. Journal of Surgical Research 23 141-148.

Dresser DW, Hacker A, Lovell-Badge R \& Guerrier D 1995 The genes for a spliceosome protein (SAP62) and the anti-Mullerian hormone (AMH) are contiguous. Human Molecular Genetics 4 $1613-1618$

Faure E, Gouedard L, Imbeaud S, Cate R, Picard JY, Josso N \& di Clemente N 1996 Mutant isoforms of the anti-Mullerian hormone type II receptor are not expressed at the cell membrane. Journal of Biological Chemistry 271 30571-30575.

Franzen P, ten Dijke P, Ichijo H, Yamashita H, Schulz P, Heldin CH \& Miyazono K 1993 Cloning of a TGF- $\beta$ type I receptor that forms a heteromeric complex with the TGF-B type II receptor. Cell 75 681-692.

Giuili G, Shen WH \& Ingraham HA 1997 The nuclear receptor SF1 mediates sexually dimorphic expression of Mullerian inhibiting substance, in vivo. Development 124 1799-1807.

Guerrier D, Tran D, Vanderwinden JM, Hideux S, Van Outryve L, Legeai L, Bouchard M, Van Vliet G, De Laet MH, Picard JY et al. 1989 The persistent Mullerian duct syndrome: a molecular approach. Journal of Clinical Endocrinology and Metabolism 68 46-52.

Gustafson ML, Lee MM, Scully RE \& Moncure AC 1992 Mullerian inhibiting substance as a marker for ovarian sex-cord tumor. New England Journal of Medicine 326 466-471.

Haqq CM, King CY, Donahoe PK \& Weiss MA 1993 SRY recognizes conserved DNA site in sex-specific promoters. Proceedings of the National Academy of Sciences of the USA 90 1097-1101.

Haqq CM, King CY, Ukiyama E, Falsafi S, Haqq TN, Donahoe PK \& Weiss MA 1994 Molecular basis of mammalian sexual determination: activation of Mullerian inhibiting substance gene expression by SRY (published erratum appears in Science 1995267 317) Science 266 1494-1500.

Harley VR, Lovell-Badge R \& Goodfellow PN 1994 Definition of a consensus DNA binding site for SRY. Nucleic Acids Research 22 1500-1501.

He WW, Gufstafson ML, Hirobe S \& Donahoe PK 1993 Developmental expression of four novel serine/threonine kinase receptors homologous to the activin/transforming growth factor-beta type II receptor family. Developmental Dynamics 196 133-142.

Hirobe S, He WW, Lee MM \& Donahoe PK 1992 Mullerian inhibiting substance messenger ribonucleic acid expression in granulosa and Sertoli cells coincides with their mitotic activity. Endocrinology 131 854-862.

Hutson J, Davidson PM, Reece LA, Baker ML \& Zhou B 1994 Failure of gubernacular development in the persistent Mullerian duct syndrome allows herniation of the testis. Pediatric Surgery International 9 544-546.

Hutson JM, Hasthorpe S \& Heyns CF 1997 Anatomic and functional aspects of testicular descent and cryptorchidism. Endocrine Reviews 18 259-280.

Ikeda Y, Lala DS, Luo X, Kim E, Moisan MP \& Parker KL 1993 Characterization of the mouse FTZ-F1 gene, which encodes a key regulator of steroid hydroxylase gene expression. Molecular Endocrinology 7 852-860.

Ikeda Y, Luo X, Abbud R, Nilson JH \& Parker KL 1995 The nuclear receptor steroidogenic factor 1 is essential for the formation of the ventromedial hypothalamic nucleus. Molecular Endocrinology 9 478-486.

Imbeaud S, Belville C, Messika-Zeiton L, Rey R, di Clemente N, Josso N \& Picard JY 1996 A 27 base-pair deletion of the
anti-Mullerian type II receptor gene is the most common cause of the persistent Mullerian duct syndrome. Human Molecular Genetics 5 $1269-1277$.

Josso N, Picard JY \& Tran D 1977 The anti-Mullerian hormone. Recent Progress in Hormone Research 33 117-160.

Kuroda T, Lee MM, Haqq CM, Powell DM, Manganaro TF \& Donahoe PK 1990 Mullerian inhibiting substance ontogeny and its modulation by follicle-stimulating hormone in the rat testes. Endocrinology 127 1825-1832.

Lee MM \& Donahoe PK 1993 Mullerian inhibiting substance: a gonadal hormone with multiple functions. Endocrine Reviews $\mathbf{1 4}$ 152-164.

Lee MM, Donahoe PK, Hasegawa T, Silverman B, Crist GB, Best S, Hasegawa Y, Noto RA, Schoenfeld D \& MacLaughlin DT 1996 Mullerian inhibiting substance in humans: normal levels from infancy to adulthood. Journal of Clinical Endocrinology and Metabolism 81 571-576.

Lee MM, Donahoe PK, Silverman BL, Hasegawa T, Hasegawa Y, Gustafson ML, Chang YC \& MacLaughlin DT 1997 The infant with ambiguous genitalia: measurements of serum mullerian inhibiting substance in the evaluation of children with nonpalpable gonads. Current Therapy in Endocrinology and Metabolism 6 216-223.

Luo X, Ikeda Y \& Parker KL 1994 A cell-specific nuclear receptor is essential for adrenal and gonadal development and sexual differentiation. Cell 77 481-490.

MacLaughlin DT, Hudson PL, Graciano AL, Kenneally MK, Ragin RC, Manganaro TF \& Donahoe PK 1992 Mullerian duct regression and anti-proliferative properties of Mullerian inhibiting substance reside in its carboxy-terminal domain. Endocrinology 131 291-296.

Massague J 1990 The transforming growth factor- $\beta$ family. Annual Review of Cell Biology 6 597-641.

Massague J, Attisano L \& Wrana JL 1994 The TGF- $\beta$ family and its composite receptors. Trends in Cell Biology 4 172-178.

Miller HC \& Futrakul P 1968 Birth weight, gestational age, and sex as determining factors in the incidence of respiratory distress syndrome of prematurely born infants. Journal of Pediatrics $\mathbf{7 2}$ 628-635.

Mishina Y, Rey R, Finegold MJ, Matzuk MM, Josso N, Cate RL \& Behringer RR 1996 Genetic analysis of the Mullerian-inhibiting substance signal transduction pathway in mammalian sexual differentiation. Genes and Development 10 2577-2587.

Munsterberg A \& Lovell-Badge R 1991 Expression of the mouse anti-Mullerian hormone gene suggests a role in both the male and female sexual differentiation. Development 113 613-625.

Nachtigal M \& Ingraham HA 1996 Bioactivation of Mullerian inhibiting substance during gonadal development by a kex2/subtilisin-like endoprotease. Proceedings of the National Academy of Sciences of the USA 93 7711-7716.

Parry RL, Chin TW, Epstein J, Hudson PL, Powell DM \& Donahoe PK 1992 Recombinant human mullerian inhibiting substance inhibits human ocular melanoma cell lines in vitro and in vivo. Cancer Research 52 1182-1186.

Pepinsky RB, Sinclair LK, Chow EP, Mattliano RJ, Manganaro TF, Donahoe PK \& Cate RL 1988 Proteolytic processing of Mullerian inhibiting substance produces a transforming growth factor- $\beta$-like fragment. Journal of Biological Chemistry 263 18961-18964.

Powell JL \& Otis CN 1997 Management of advanced juvenile granulosa cell tumor of the ovary. Gynecologic Oncology 64 282-284.

Rey RA, Lhomme C, Marcillac I, Lahlou N, Duvillard P, Josso N \& Bidart JM 1996 Anti-Mullerian hormone as a serum marker of granulosa cell tumors of the ovary: comparative study with serum alpha inhibin and estradiol. American Journal of Obstetrics and Gynecology 174 958-965.

Shen WH, Moore CC, Ikeda Y, Parker KL \& Ingraham HA 1994 Nuclear receptor steroidogenic factor 1 regulates the Mullerian inhibiting substance gene: a link to the sex determination cascade. Cell 77 651-661. 
Taguchi O, Cunha GR, Lawrence WD \& Robboy SJ 1984 Timing and irreversibility of Mullerian duct inhibition in the embryonic reproductive tract of the human male. Developmental Biology 106 394-398.

Takahashi M, Koide SS \& Donahoe PK 1986 Mullerian inhibiting substance as oocyte meiosis inhibitor. Molecular and Cellular Endocrinology 47 225-234.

Taketo T, Saeed J, Manganaro T, Takahashi M \& Donahoe PK 1993 Mullerian inhibiting substance production associated with loss of oocytes and testicular differentiation in the transplanted mouse XX gonadal primordium. Biology of Reproduction 49 13-23.

Teixeira J \& Donahoe PK 1996a Molecular biology of MIS and its receptors. Journal of Andrology 17 336-341.

Teixeira J, He WW, Shah PC, Morikawa N, Lee MM, Catlin EA, Hudson PL, Wing J, MacLaughlin DT \& Donahoe PK 19966 Developmental expression of a candidate Mullerian inhibitory substance type II receptor. Endocrinology 137 160-165.

Torday JS, Nielsen HC, Fencl M \& Avery ME 1981 Sex differences in fetal lung maturation. American Review of Respiratory Diseases 123 205-208.

Tsuji M, Shima H, Yonemura CY, Brody J, Donahoe PK \& Cunha GR 1992 Effect of human recombinant Mullerian inhibiting substance on isolated epithelial and mesenchymal cells during Mullerian duct regression in the rat. Endocrinology 131 1481-1488.

Ueno S, Kuroda T, MacLaughlin DT, Ragin RC, Manganaro TF \& Donahoe PK 1989a Mullerian inhibiting substance in the adult rat ovary during various stages of the estrous cycle. Endocrinology $\mathbf{1 2 5}$ 1060-1066.

Ueno S, Takahashi M, Manganaro TF, Ragin RC \& Donahoe PK $1989 b$ Cellular localization of Mullerian inhibiting substance in the developing rat ovary. Endocrinology 124 1000-1006.

Wang T, Donahoe PK \& Zervos AS 1994 Specific interaction of type I receptors of the TGF- $\beta$ family with the immunophilin FKBP-12. Science 265 674-676.

Wang T, Danielson P, Li B-Y, Shah P, Kim S \& Donahoe P 1996 The p21ras farensyltransferase alpha subunit in TGF- $\beta$ and activin signaling. Science 271 1120-1122.

Zon LI, Youssoufian H, Mather C, Lodish HF \& Orkin SH 1991 Activation of the erythropoeitin receptor promoter by transcription factor GATA-1. Proceedings of the National Academy of Sciences of the USA 88 10638-10641.

Received 17 November 1997

Accepted 16 February 1998 